\title{
Pengaruh Pemberian Pakan Sumber Energi terhadap Profil Darah Kambing Kacang Jantan
}

\section{Joni Ordianus Bere ${ }^{\mathrm{a}}$, Stefanus Sio ${ }^{\mathrm{b}}$, Gerson Frans Bira ${ }^{\mathrm{c}}$}

${ }^{a}$ Fakultas Pertanian, Universitas Timor, Kefamenanu, TTU-NTT, Indonesia, email : joniordianusbere@gmail.com

${ }^{b}$ Fakultas Pertanian, Universitas Timor, Kefamenanu, TTU-NTT, Indonesia, email : stefsio67@gmail.com

${ }^{c}$ Fakultas Pertanian, Universitas Timor, Kefamenanu, TTU-NTT, Indonesia, email : gersonbira@yahoo.co.id

\section{Article Info}

\section{Article history:}

Received 16 Mei 2019

Received in revised form 22 Agustus 2018

Accepted 22 Oktober 2019

DOI:

\section{Keywords:}

Pakan Sumber Energi

Kambing Kacang

Profil Darah https://doi.org/10.32938/ja.v4i4.675

\begin{abstract}
Abstrak
Penelitian ini dilaksanakan di Desa Nunmafo, Kecamatan Insana, Kabupaten TTU. Tujuan dari penelitian ini adalah untuk mengetahui pengaruh pemberian pakan sumber enegi terhadap profil darah ternak kambing kacang jantan. Tujuan dari penelitian ini adalah untuk mengetahui pengaruh pemberian pakan sumber enegi terhadap profil darah komplit pada ternak kambing kacang jantan. Perlakuan yang diuji dalam penelitian ini terdiri dari $\mathrm{R} 0=80 \%$ rumput alam $+20 \%$ lamtoro. $\mathrm{R} 1=50 \%$ rumput alam $+20 \%$ lamtoro $+30 \%$ jagung. $\mathrm{R} 2$ $=50 \%$ rumput alam $+20 \%$ lamtoro $+30 \%$ dedak padi. $\mathrm{R} 3=50 \%$ rumput alam $+20 \%$ lamtoro $+30 \%$ gaplek. Hasil penelitian menunjukkan bahwa pemberian pakan sumber energi pada kambing kacang jantan tidak berpengaruh nyata terhadap kadar glukosa darah pada 0, 4 dan 6 jam namun berpengaruh nyata $(\mathrm{P}>0,05)$ pada 2 jam setalah diberi pakan, sedangkan untuk kadar Hemoglobin, Hematokrit, Total Protein Plasma tidak berpengaruh nyata. Berdasarkan hasil penelitian ini dapat disimpulkan bahwa pemberian pakan sumber energi yang berbeda tidak mempengaruhi profil darah kambing kacang jantan secara umum namun sedikit mempengaruhi kadar glukosa darah pada pengambilan 2 jam setelah diberi pakan dan total protein plasma 6 jam setelah diberi pakan. Terjadi peningkatan kadar darah dari kadar darah normalnya.
\end{abstract}

\section{Pendahuluan}

Kambing kacang merupakan kambing lokal Indonesia yang memiliki keunggulan antara lain pemeliharaan yang mudah serta memiliki daya adaptas yang tinggi terhadap kondisi alam setempat (Sumardianto et al., 2013). Selain itu kemampuan reproduksi kambing kacang juga cukup baik, pada umur 15-18 bulan sudah bisa menghasilkan keturunan (Mahmilia et al., 2009). Kambing kacang juga merupakan salah satu bangsa kambing lokal yang berpotensi baik dalam menghasilkan karkas dan non karkas (Kusuma et al., 2013). Kegunaan dari kambing kacang adalah sebagai ternak penghasil daging (Karstan, 2006), sehingga berpotensi membantu memenuhi kebutuhan protein hewani bag masyarakat. Rendahnya kulitas pakan menyebabkan kurangnya nutrien yang dapat di serap oleh tubuh ternak sehingga akan berpengaruh pada fungsi fisiologisnya seperti darah.

Gambaran darah glukosa, urea, total protein plasma, hemaglobin dan hamatokrit yang rendah akan mempengaruhi kondisi tubuh ternak dan akan menimbulkan berbagai penyakit diantaranya anemia (turunnya sel darah merah atau kadar hemoglobin dalam darah). Untuk mencapai kondisi darah yang normal perlu memperbaiki pemberian pakan sumber energi.

Dalam menunjang pertumbuhan dan perkembangan ternak kambing maka faktor pakan harus menjadi perhatian yang serius karena merupakan faktor terpenting (60-70\% dari total biaya). Nutrisi pakan sudah menjadi hal penting yang harus dilihat dan dihitung oleh peternak dan pengusaha yang bergerak dibidang peternakan khususnya ternak kambing sehingga produks ternak kambing dapat tercapai secara maksimal. Pemberian pakan sumber energi sangat penting untuk pemanfaatan darah dalam tubuh ternak, karena pakan yang di konsumsi akan diserap kedalam jaringan darah untuk di transfe kedalam tubuh ternak melalui jaringan-jaringan saraf pada ternak (Mahest 2009). Diharapkan dengan pemberian pakan sumber energi maka keadaan atau status fisiologi kambing kacang jantan dapat berjalan dengan cepat dan normal sehingga membantu meningkatkan produktifitasnya. Tujuan dari penelitian in adalah untuk mengetahui pengaruh pemberian pakan sumber enegi terhadap profil darah komplit pada ternak kambing kacang jantan.

\section{Metode}

\subsection{Waktu dan Tempat Penelitin}

Penelitian ini akan dilaksanakan di Desa Nunmafo, Kecamatan Insana, Kabupaten TTU. Waktu penelitian direncanakan berlangsung selama 12 minggu (90 hari) termasuk persiapan dan pelaksanaan penelitian. Penelitian berlangsung selama 4 bulan di tahun 2018. Analisis darah dilaksanakan di Laboratorium Bio Reproduksi dan Kesehatan Ternak Fakultas Peternakan Universitas Nusa Cendana

\subsection{Alat dan Bahan}

Adapun peralatan yang digunakan dalam penelitian ini adalah tabung EDTA, termos es, holder vacautainer, naald vacautainer serta peralatan dalam analisis darah dan peralatan lain seperti parang, ember, alat tulis dan kamera Bahan yang digunakan dalam penelitian ini terdiri dari : rumput alam, daun lamtoro yang diperoleh di sekitar lokasi penelitian, dan konsentrat tepung jagung, dedak padi, dan ubi kayu serta bahan dalam analisis darah.

\subsection{Metode Penelitian}

Penelitian ini menggunakan Rancangan Acak Kelompok (RAK) yang terdiri dari 4 perlakuan dan 3 ulangan. Adapun perlakuan yang akan diuji terdiri dari :

$\mathrm{R}_{0}: 80 \%$ Rumput Alam $+20 \%$ Lamtoro

$\mathrm{R}_{1}: 50 \%$ Rumput Alam $+20 \%$ Lamtoro $+30 \%$ Jagung

$\mathrm{R}_{2}: 50 \%$ Rumput Alam $+20 \%$ Lamtoro $+30 \%$ Dedak Pad

$\mathrm{R}_{3}: 50 \%$ Rumput Alam $+20 \%$ Lamtoro $+30 \%$ Ubi Kayu

Kandungan nutrisi bahan pakan penelitian dapat dilihat pada Tabel 1 dan jumlah pemberian pakan perlakuan pada ternak kambing (Tabel 2).
Tabel 1. Kandungan Nutrisi Bahan Pakan Penelitian

$\mathrm{EM}(\mathrm{Kkal} / \mathrm{kg} \mathrm{BK}) * * \quad 2.761,13 \quad 3.599,59 \quad 3.679,99 \quad 4.276,704.112,39$

Keterangan: $\quad B K=$ Bahan Kering. $P K=$ Protein Kasar. $L K=$ Lemak Kasar. $S K=$ Serat Kasar. $C H O=$ Karbohidrat. BETN $=$ Bahan Ekstrak Tanpa Nitrogen $* *$ Perhitungan Dari Parameter

Tabel 2. Jumlah Pemberian Pakan Segar Ternak Kambing Penelitian

\begin{tabular}{|c|c|c|c|}
\hline Perlakuan & Pakan & $\begin{array}{c}\text { Jumlah } \\
\text { pemberian } \\
(\%)\end{array}$ & Konsumsi pakan (kg/ekor/hari) \\
\hline \multirow{2}{*}{ R0 } & Rumput Alam & $80 \%$ & 2.20 \\
\hline & Lamtoro & $20 \%$ & 0.55 \\
\hline \multirow{3}{*}{ R1 } & Rumput Alam & $50 \%$ & 1.376 \\
\hline & Lamtoro & $20 \%$ & 0.55 \\
\hline & Jagung & $30 \%$ & 0.205 \\
\hline \multirow{3}{*}{$\mathrm{R} 2$} & Rumput Alam & $50 \%$ & 1.376 \\
\hline & Lamtoro & $20 \%$ & 0.55 \\
\hline & Dedak padi & $30 \%$ & 0.200 \\
\hline \multirow{3}{*}{ R3 } & Rumput Alam & $50 \%$ & 1.376 \\
\hline & Lamtoro & $20 \%$ & 0.55 \\
\hline & Gaplek & $30 \%$ & 0.200 \\
\hline
\end{tabular}

\subsection{Pembuatan Kandang}

Kandang yang digunakan dalam penelitian ini adalah kandang individu tipe panggung yang terbuat dari kayu dan bambu yang beratap seng terdiri dar 12 petak dan dibagi dalam 2 blok dimana setiap blok terdiri dari 6 petak kandang dan tiap petak berukuran $1 \times 1 \mathrm{~m}$ yang telah dilengkapi tempat makan dan minum.

\subsection{Pembutan Pakan Pakan Sumber Energi}

Bahan dasar pembuatan pakan sumber energi terdiri dari jagung, dedak padi dan gaplek. Pembuatan pakan sumber energi dilakukan dengan mengeringkan bahan dasar dengan metode pengeringan matahari selama 7 har selanjutnya bahan digiling dan dihaluskan dengan menggunakan mesin giling sampai bahan berubah bentuk menjadi tepung.

\subsection{Masa Preliminari}

Masa preliminari bertujuan untuk membiasakan ternak untuk beradaptasi terhadap lingkungan yang baru, serta membiasakan ternak terhadap ransum yang akan diuji. Masa preliminari dilakukan selama satu minggu.

\subsection{Pemeliharaan}

Pemeliharaan ternak meliputi pemberian pakan dimana setiap harinya ternak diberikan pakan berupa rumput alam dan lamtoro dalam bentuk segar di sesuaikan dengan rancangan penelitian, dan pakan sumber energi berupa tepung jagung, tepung gaplek dan dedak padi. Pemberian pakan pada ternak diberikan 2x sehari yaitu pagi dan sore.

\begin{tabular}{lcccccc}
\hline \multirow{2}{*}{ Nutrisi } & \multicolumn{5}{c}{ Bahan Pakan } \\
\cline { 2 - 6 } & $\begin{array}{r}\text { Rumput } \\
\text { lapangan }\end{array}$ & Lamtoro & $\begin{array}{c}\text { Dedak } \\
\text { Padi }\end{array}$ & Jagung & Gaplek \\
\hline BK (\%) & 35,500 & 27,500 & 87,991 & 88,271 & 87,828 \\
BO (\%) & 91,49 & 93,44 & 88,84 & 98,68 & 97,56 \\
PK (\%) & 9,74 & 26,85 & 11,20 & 7,82 & 2,18 \\
LK (\%) & 3,67 & 7,41 & 7,42 & 4,99 & 0,63 \\
SK (\%) & 29,66 & 13,90 & 8,82 & 2,14 & 0,91 \\
CHO (\%BK)** & 78,07 & 59,17 & 70,21 & 85,86 & 94,74 \\
BETN (\%BK) $* * *$ & & 48,40 & 45,27 & 61,39 & 83,72 & 93,83 \\
Gross Energy & $(\mathrm{MJ} / \mathrm{Kg}$ & 12,87 & 14,25 & 13,34 & 14,04 & 17,14 \\
BK)** & & & & & &
\end{tabular}




\subsection{Pengambilan Data}

Pada akhir periode penelitian dilakukan pengambilan data berupa pengambilan darah pada vena jugularis kambing sebanyak $10 \mathrm{ml}$. Sampel darah dimasukan ke dalam tabung darah yang telah terisi EDTA dan di bawah ke Laboratorium untuk dianalisis. Pengambilan sampel darah di lakukan pada 0 jam sebelum ternak memperoleh pakan kemudian 2, 4 dan 6 setelah ternak mengkonsumsi pakan.

\subsection{Variabel Penelitian}

Variabel yang di ukur dalam penelitian ini adalah : kadar glukosa, kadar urea, total protein plasma (TPP), hemaglobin, hematokrit, eritrosit dan leukosit.

\subsection{Analisis Data}

Data yang diperoleh dalam penelitian ini dianalisis menggunakan analisis sidik ragam (Anova), dilanjutkan dengan uji jarak berganda Duncan untuk melihat perbedaan antara perlakuan sesuai petunjuk Steel dan Torrie (1993). Analisis data menggunakan program SAS versi 91.

\section{$3 \quad$ Hasil dan Pembahasan}

\subsection{Pengaruh Perlakuan Terhadap Glukosa Darah}

Kadar glukosa, total protein, albumin dan urea darah pada ternak mencerminkan pemberian pakan pada kambing yang dicerna oleh saluran pencernaan hingga terabsorbsi dan masuk dalam darah yang beredar keseluruh tubuh. Kadar glukosa dalam darah merefleksikan sumber energi dalam tubuh (Church dan Pond, 1988). Ternak akan menjadi lemah bila energi tidak mencukupi dalam darah atau hipoglikemia yang dapat terjadi pada kambing yang kurang pakan. Kadar glukosa dalam darah pada kambing kacang jantan yang diberi pakan sumber energi berbeda dapat dilihat pada Tabel 3.

Tabel 3. Kadar Glukosa Darah (mg/dl) Kambing Kacang Jantan yang diambil 0,2,4 dan 6 jam Pakan Sumber Energi yang berbeda.

\begin{tabular}{ccccc}
\hline \multirow{2}{*}{ Waktu Pengambilan Darah } & \multicolumn{4}{c}{ Perlakuan } \\
\cline { 2 - 5 } & R0 & R1 & R2 & R3 \\
\hline 0 Jam & 97.29 & 91.14 & 100.65 & 95.46 \\
2 Jam & $117.11^{\mathrm{a}}$ & $105.37^{\mathrm{b}}$ & $107.84^{\mathrm{b}}$ & $105.31^{\mathrm{b}}$ \\
4 Jam & 99.33 & 104.01 & 104.74 & 107.64 \\
6 Jam & 111.77 & 106.97 & 103.93 & 100.47 \\
\hline
\end{tabular}

Keterangan: Nilai dengan superskrip yang berbeda dalam kolom yang sama menunjukan pengaruh nyata $(P<0.05)$

Data pada Tabel 3 menunjukkan bahwa darah kambing kacang jantan yang diambil pada 0 jam, 4 jam dan 6 jam setelah diberi pakan dengan sumber energi berbeda tidak memberikan pengaruh terhadap kadar glukosa darah. Faktor yang mempengaruhi glukosa darah yaitu pencernaan karbohidrat dan metabolisme energi dalam tubuh. Namun ada perbedaan pada pengambilan darah 2 jam setelah diberi pakan dengan sumber energi berbeda. Hal ini dapat terjadi karena kadar glukosa darah meningkat pada 2 jam setelah makan, karena aktivitas hormon insulin untuk menyetabilkan kadar glukosa darah naik dengan cara mendorong glukosa darah menjadi glikogen hati dan otot. Seperti dijelaskan oleh (Murray et al., 2003) bahwa bila kadar glukosa darah naik hormon insulin meningkat sehingga akan mempercepat masuknya glukosa ke dalam hati dan otot dimana glukosa akan di ubah menjadi glikogen. Selain tambahan dari pakan sumber karbohidrat yang mudah larut, proses fermentasi pakan berserat di rumen akan menghasilkan propionat yang dapat berperan sebagai precursor pembentukan glukosa baru melalui jalur glukoneogenesis. Namun yang menjadi perhatian adalah kadar glukosa darah yang dihasilkan dari penelitian ini tergolong tinggi karena menurut Kendran et al.,(2012). Kandungan glukosa darah normal pada kambing adalah 44-81 mg/dl sedangkan (Ginting, 2012), kadar glukosa normal pada kambing yaitu $50-80 \mathrm{mg} / \mathrm{dl}$. Karbohidrat merupakan sumber energi (Sarwono, 2008). Faktor yang mempengaruhi glukosa darah yaitu pencernaan karbohidrat dan metabolisme energi dalam tubuh. Glukosa darah pada ternak ruminansia tidak hanya berasal dari sakarida pakan tetapi dari volatile fatty acid (VFA) yang berasal dari pencernaan serat kasar. Karbohidrat akan difermentasi oleh mikroba rumen mnjadi VFA, utamanya asetat, propionat dan butirat yang digunakan sebagai sumber energi utama ternak ruminansia. Hal yang akan terjadi dengan kadar glukosa darah yang tinggi ini adalah akan menyebabkan sekresi insulin untuk menghambat proses glukoneogenesis, menghambat pelepasan glukosa dari hati dan menghambat proteolisis dan lipolisis (Adriani dan Mushawwir, 2009).

\subsection{Pengaruh Perlakuan Terhadap Urea Darah.}

Urea dalam darah meningkat dapat disebabkan oleh makanan. Urea dihasilkan oleh hati sebagai sisa deaminasi asam amino, bila kadar tinggi dalam darah maka akan dibuang melalui ginjal (Kirtane, 2005). Urea darah dihasilkan dari perombakan amonia yang diabsorbsi lewat vena portal bersama $\mathrm{CO}_{2} \mathrm{di}$ dalam hati (Fajar, 2013). Untuk melihat kadar urea darah ternak kambing kacang yang diberi pakan sumber energi berbeda tersaji dalam Tabel 4.

Hasil uji statistik menunjukkan bahwa tidak ada pengaruh kadar urea darah kambing kacang jantan yang diambil 0 (sebelum diberi pakan) dan 2, 4 dan 6 jam setelah diberi pakan sumber energi. Ternak yang mengkonsumsi pakan tujuan utamanya adalah untuk memenuhi kebutuhan energinya, jika kebutuhan energinya terpenuhi maka ternak akan berhenti untuk makan. Hal ini yang mendasari bahwa walaupun kandungan energi ataupun protein masingmasing pakan yang diberikan pada ternak kambing sedikit berbeda namun ketika ternak telah tercukupi energinya maka ternak akan berhenti makan akibatnya kadar urea darah yang merupakan hasil metabolisme protein melalui sekresi lewat urin akan tetap sama. Hal ini didukung oleh pernyataan Fachiroh et al., (2012) bahwa urea darah adalah hasil akhir dari metabolisme protein dalam tubuh hewan dan diekskresikan melalui urin, sedangkan urea darah berasal dari amonia rumen dan sisa metabolisme asam amino. Hal lain yang diperoleh adalah pemberian pakan sumber energi tidak berpengaruh nyata terhadap kadar urea darah karena kadar urea darah memiliki hubungan yang positif dengan protein pakan (Wanapat, 2006). Namun data pada Tabel 4 di atas masih dalam kisaran normal kadar urea darah dalam tubuh. Menurut Arifin dan Zulfanita, (2012) kisaran kadar urea normal adalah antara 26,6 dan 56,7 mg/dl yang mencerminkan bahwa mikroba dalam rumen maksimal dalam mempergunakan amonia untuk perkembangannya.

Tabel 4. Kadar urea darah (mg/dl) kambing kacang jantan yang diambil sebelum dan sesudah mengkonsumsi pakan sumber energi yang berbeda.

\begin{tabular}{ccccc}
\hline \multirow{2}{*}{ Waktu Pengambilan Darah } & \multicolumn{4}{c}{ Perlakuan } \\
\cline { 2 - 5 } & R0 & R1 & R2 & R3 \\
\hline 0 Jam & 48.493 & 48.612 & 50.890 & 48.059 \\
2 Jam & 47.225 & 49.820 & 48.832 & 50.290 \\
4 Jam & 51.095 & 53.996 & 53.299 & 50.901 \\
6 Jam & 48.990 & 51.075 & 50.009 & 49.136 \\
\hline
\end{tabular}

\subsection{Pengaruh Perlakuan Terhadap Total Protein Plasma darah}

Darah terdiri dari benda-benda korposkuler dan cairan yang disebut plasma dan juga total protein. Serum darah dapat menggambarkan status gizi dari ternak itu sendiri. Plasma darah adalah campuran protein anion kation yang sangat kompleks. Plasma protein terdiri dari beberapa kelompok. Gambaran Total Protein Plasma darah kambing kacang yang diberi pakan sumber energi berbeda dapat dilihat pada Tabel 5 .

Tabel 5. Total protein plasma darah (g/dl) kambing kacang jantan yang diambil $0,2,4$,dan 6 jam sesudah mengkonsumsi pakan sumber energi yang berbeda.

\begin{tabular}{ccccc}
\hline \multirow{2}{*}{ Waktu Pengambilan Darah } & \multicolumn{4}{c}{ Perlakuan } \\
\cline { 2 - 5 } & $\mathrm{R} 0$ & $\mathrm{R} 1$ & $\mathrm{R} 2$ & $\mathrm{R} 3$ \\
\hline 0 Jam & 6.60 & 6.40 & 7.00 & 7.60 \\
2 Jam & 6.73 & 6.97 & 7.07 & 7.13 \\
4 Jam & 7.00 & 6.97 & 7.30 & 6.43 \\
6 Jam & $6.03^{\mathrm{b}}$ & $5.97^{\mathrm{b}}$ & $6.47^{\mathrm{a}}$ & $7^{\mathrm{b}}$ \\
\hline Keterangan: & Nilai dengan superskrip yang berbeda dalam kolom yang sama menunjukan
\end{tabular}
pengaruh nyata $(P<0.05)$

Data pada Tabel 5 menunjukkan bahwa pemberian pakan sumber energi yang berbeda pada kambing kacang jantan tidak mempengaruhi TPP namun pada pengambilan darah pada 6 jam setelah diberi pakan menunjukkan perbedaan nyata $(\mathrm{P}<0,05)$. Kadar protein plasma darah yang dihasilkan berkisar antara 5,97 - 7,60 g/dl dan hal ini sedikit lebih tinggi dari yang dilaporkan oleh Wahjuni et al. (2011) bahwa kadar protein plasma darah kambing kacang yang diberi pakan sumber energi berkisar antara 5,28-6,28 g/dl serta pernyataan Mitruka et al. (2016) bahwa protein plasma darah normal pada kambing kacang berkisar antara 4,5-7,2 g/dl. Tingginya kadar protein plasma darah dalam penelitian ini menggambarkan bahwa pakan yang diberikan pada ternak sangat mencukupi dalam hal nutrisinya. Sehingga kadar dehidrasi meningkat dan total protein plasma lebih tinggi dari kadar normalnya. Kadar dehidrasi mempunyai hubungan yang erat dengan total protein plasma kambing kacang. Hal in didukung oleh Kaneko, (2004) bahwa peningkatan total protein plasma dipengaruhi oleh kadar dehidrasi. Gambaran total protein plasma dan hemoglobin pada ternak sangat berpengaruh terhadap produktivitas ternak karena jumlah total protein plasma yang terkandung di dalam darah mempengaruhi sistem imun tubuh ternak. Pada pengambilan darah 6 jam setelah diberi pakan berpengaruh nyata terhadap kadar protein plasma darah karena ternak mengalami cekaman stres akibat vena jungularisnya yang harus dilukai untuk mengambil darahnya.

\subsection{Pengaruh Perlakuan Terhadap Hemoglobin darah}

Hemoglobin darah dapat diukur berdasarkan intensitas warnanya dengan menggunakan fotometer dan dinyatakan dalam gram hemoglobin per seratus meter $(\mathrm{g} / 100 \mathrm{ml})$ atau gram per desiliter $(\mathrm{g} / \mathrm{dl})$ (Arifin, 2013). Hemoglobin penting untuk keberlangsungan hidup karena membawa dan mengatur oksigen ke jaringan tubuh (Jain, 2012). Hemoglobin secara fisik memiliki hubungan dengan oksigen. Intensitas warna hemoglobin bergantung pada banyaknya oksigen. Kadar hemoglobin darah kambing kacang jantan yang diberi pakan sumber energi berbeda dapat dilihat pada Tabel 6 .

Tabel 6 menunjukkan bahwa kadar hemoglobin darah yang diambil sebelum mengkonsumsi dan sesudah mengkonsumsi pakan sumber energi berkisar berkisar antara 16,92-23,94 g/dl. Berdasarkan analisis statistik bahwa pemberian pakan sumber energi tidak memberikan pengaruh terhadap kadar hemoglobin darah kambing kacang jantan. Hal ini dapat disebabkan karena dipengaruhi oleh kualitas dan kuantitas pakan yang diberikan terutama protein 
terhadap pembentukan sel darah merah dan hemoglobin darah dalam sumsum tulang. Kadar hemoglobin darah pada kambing kacang jantan lebih tinggi dari hasil penelitian di atas karena oksigen yang terdapat pada tubuh ternak lebih tinggi,hal itu bisa di lihat pada larutan warnahnya akan berwarna merah cerah. Widiyono et al. (2014) menyatakan bahwa kadar hemoglobin kambing PE dinyatakan normal jika dalam kisaran 11,30 - 12,20 g/100 ml, dalam kondisi ini dapat dikatakan bahwa kambing tersebut dalam kondisi yang sehat.

Tabel 6. Kadar hemoglobin darah (g/dl) kambing kacang jantan yang diambil $0,2,4$, dan 6 jam sesudah mengkonsumsi pakan sumber energi yang berbeda.

\begin{tabular}{ccccc}
\hline \multirow{2}{*}{ Waktu Pengambilan Darah } & \multicolumn{4}{c}{ Perlakuan } \\
\cline { 2 - 5 } & R0 & R1 & R2 & R3 \\
\hline 0 Jam & 23.19 & 23.94 & 23.11 & 24.23 \\
2 Jam & 19.66 & 24.81 & 22.77 & 24.30 \\
4 Jam & 16.92 & 21.83 & 20.85 & 19.93 \\
6 Jam & 17.17 & 21.53 & 24.42 & 19.06 \\
\hline
\end{tabular}

Kadar hemoglobin cenderung lebih rendah disebabkan karena pakan kambing kacang hanya berupa hijauan yang diperoleh saat digembalakan (Rahayu et al., 2017) dan sedikit berbeda pada penilitian ini karena pakan yang diberikan merupakan konsentrat dan terdiri dari berbagai jenis pakan yang kandungan nutrisinya dapat mencukupi kebutuhan ternak kambing sehingga kadar hemoglobin meningkat. Walaupun zat besi (Fe) dalam pakan tidak diukur namun tingginya kadar hemoglobin dalam penelitian ini kemungkinan besar disebabkan oleh kandungan zat besi (Fe) dalam pakan. Zat besi akan sangat diperlukan dalam proses pembentukan eritrosit yakni dalam mensintesa hemoglobin (Arifin, 2008). Kemudian dijelaskan lebih lanjut oleh Rahayu et al. (2017), zat besi merupakan komponen utama dari hemoglobin sehingga kekurangan zat besi akan menurunkan kadar hemoglobin.

Kondisi hemoglobin tinggi biasanya juga terjadi akibat reaksi tubuh saat kadar oksigen turun. Tubuh berusaha untuk segera memasok oksigen lewat $\mathrm{Hb}$ dengan kata lain bahwa kambing kacang jantan yang digunakan dalam penelitian ini mengalami cekaman stress akibat kondisi lingkungan yang panas dan pengambilan darah yang secara berulang dari 0, 2, 4 dan 6 jam. Menurun dan meningkatnya kadar hemoglobin juga sangat dipengaruhi oleh musim, aktifitas tubuh, serta ada tidaknya kerusakan eritrosit, nutrisi dalam pakan dan penanganan darah saat pemeriksaan (Andriyanto et al., 2010).

\subsection{Pengaruh perlakuan terhadap kadar Hematokrit Darah}

Hematokrit adalah persentase sel darah merah dalam $100 \mathrm{ml}$ darah (Nossafadli et al., 2014). Hematokrit juga bisanya dinyatakan dalam bentuk persen (\%). Kadar Hematokrit darah kambing kacang jantan yang diberi pakan sumber energi berbeda dapat dilihat pada Tabel 7.

Tabel 7. Kadar hematokrit darah (\%) kambing kacang jantan yang diambil $0,2,4$, dan 6 jam sesudah mengkonsumsi pakan sumber energi yang berbeda.

\begin{tabular}{ccccc}
\hline \multirow{2}{*}{ Waktu Pengambilan Darah } & \multicolumn{4}{c}{ Perlakuan } \\
\cline { 2 - 5 } & R0 & R1 & R2 & R3 \\
\hline 0 Jam & 69.57 & 71.81 & 69.33 & 72.70 \\
2 Jam & 58.97 & 74.44 & 68.32 & 72.91 \\
4 Jam & 50.74 & 65.48 & 62.54 & 59.80 \\
6 Jam & 51.52 & 64.60 & 73.25 & 57.18 \\
\hline
\end{tabular}

Tabel 7 menunjukkan bahwa tidak ada pengaruh pemberian pakan sumber energi berbeda terhadap kadar hematokrit darah. Kadar hematokrit dalam penelitian ini tergolong tinggi jika dibandingkan dengan Rahayu et al., (2017) yang memperoleh rata-rata nilai hematokrit pada kambing kacang betina adalah sebesar 22,3\%, sedangkan menurut Widiyono et al. (2014) nilai hematokrit yang diperoleh sebesar $28,58 \%$.

Kadar hematokrit sebanding dengan hemoglobin dan eritrosit, jika kadar hemoglobin darah tinggi maka kemungkinan besar kadar hematokritnya tinggi. Hal ini didukung oleh (Rosadi, 2013) bahwa pada hewan normal hematokrit sebanding dengan jumlah eritrosit dan kadar hemoglobin. Kadar hematokrit yang diperoleh dalam penelitian ini tergolong tinggi yang kemungkinan besar disebabkan oleh cekaman stres sebagai akibat dari kondisi lingkungan yang panas dan pengambilan darah yang secara berulang dari 0, 2, 4 dan 6 jam. Hemoglobin, hematokrit dan eritrosit akan meningkat apabila hewan dalam keadaan takut atau hewan dalam keadaan gembira. Hal ini disebabkan karena dilepaskannya katekolamin (epineprin/norepineprin), akibatnya tekanan darah meningkat kontraksi dari limpa sehingga eritrosit akan dipindahkan untuk ikut aliran darah begitu juga jika terjadi penurunan $\mathrm{Hb}$ bisa sebabkan salah satunya oleh anemia (Suwandi, 2002). Ada beberapa faktor yang mempengaruhi perbedaan nilai hematokrit seperti umur, aktivitas ternak, konsumsi air, suhu lingkungan serta kandungan nutrisi dalam pakan terutama protein, mineral, dan vitamin sangat dibutuhkan dalam menjaga normalitas dan nilai hematokrit (Weiss dan Wardrop, 2010).

\section{Simpulan}

Pemberian pakan sumber energi yang berbeda mempengaruhi profil darah kambing kacang jantan secara umum namun sedikit mempengaruhi kadar glukosa darah pada pengambilan 2 jam setelah diberi pakan dan total protein plasma 6 jam setelah diberi pakan. Terjadi peningkatan kadar darah dari kadar darah normalnya, sehingga pemberian pakan sumber energi dapat mempengaruhi profil darah kambing kacang jantan.

\section{Pustaka}

Adriani, L dan Mushawwir, A. 2009. Kadar glukosa darah, laktosa dan produksi susu sapi perah pada berbagai tingkat suplementasi mineral makro. J.Indon.Trop.Anim.Agric, 34(2):88-95.

Andriyanto, Y. S. Rahmadani, A.S. Satyaningsih, dan S. Abadi. 2010 Gambaran hematologi domba selama transportasi: peran multivitamin dan meniran. Jurnal Ilmu Peternakan Indonesia, 15(3): 134-136.

Arifin, Z. 2008. Beberapa unsur mineral esensial mikro dalam sistem biologi dan metode analisisnya. J. Litbang. Pertanian. 27 (3): 99-105.

Arifin, H.D. dan Zulfanita. 2012. Amonia rumen dan urea darah kambing Jawarandu pengaruh pemberian daun papaya. Surya Agritama, 1 (1): 38 $-47$.

Arifin, H. D. 2013. Profil darah kambing jawaran dupengaruh substitusi atas daun papaya (Carica papaya Leaf). Surya Agritama, 2(1): 96 -104.

Church, C. D and Pond, V.G. 1988. Macro and micro minerals, In : Basic Animal Nutrition and feeding. $3^{\text {nd }}$ ed. John Wiley and Son Inc., USA.

Fachiroh, L, Prasetiyono dan Subrata,A, 2012. Kadar Prorein dan Urea Darah Kambing Perah Peranan Etawa yang Diberi Wafer Pakan Komplit Berbasis Limbah Agroindustri dengan Suplementasi Protein Terproteksi. Animal Agriculture Journal, 1 (1) : 443-451.

Fajar, A.P. 2013. Amonia Cairan Rumen, pH dan Urea Plasma Darah Kambing Kacang Jantan Yang Mendapatkan Wafer Pakan Komplit Mengandung Tongkol Jagung. Skripsi. Fakultas Peternakan, Universitas Hasanudin. Makasar.

Ginting, S.P.,A.Tarigan dan R. Krisnan.,2012. Konsumsi fermentasi rumen dan metabolit darah kambing sedang tumbuh yang diberi silase I. Arrecta dalam pakan komplit. JITV, 17 (1) : 49-58.

Jain, A. K. C. 2012. A New Classification Of Diabetic Foot Complications: A Simple And Effective Teaching Tool. The Journal of Diabetic Foot Complications, 4(1) : 1-5

Karstan A., H. 2006. Respon fisiologi ternak kambing yang dikandangkan dan ditambahkan terhadap konsumsi pakan dan air minum. J. Agroforestri, 1 (1) : 63-73

Kaneko, H., 2004. Individual Investor Behaviour. Japan : Nomura Research Institute, $1-15$

Kendran, A.A.G., Damriyasa, I.M., Dharmawan, N.S., Ardhana, I.B.K. dan Anggreni, L.D., 2012. Profil Kimia Klinik Darah Sapi Bali.Jurnal Veteriner. 13 (4): 410-41

Kirtane, A. J., Leder, D. M., Waikar, S. S., Cherto w, G. M., Ray K. K., Pinto, D. S., Karmpaliotis, D., Burger, A. J., Murphy, S. A.,Cannon, C. P., Braunwald, E. and Gibson, C. M. 2005. Serum Blood Urea Nitrogen as an Independent Marker of Subsequent Mortality Among Pa tients With Acute Coronary Syndromes and Normal to Mildly Reduced Glo merular Filtration Rates J. Am Coll Cardiol, 45:1781-1786.

Kusuma, A. 2013. Persentase Non Karkas Kambing Kacang, Kambing Peranakan Ettawa (PE) dan Kambing Kacang Jantan Umur Satu Tahun. Fakultas Peternakan dan Pertanian, Universitas Diponegoro, Semarang.

Mahesti, G, 2009. Pemanfaatan Protein pada Domba Lokal Jantan Dengan Bobot Badan dan Aras Pemberian Pakan yang Berbeda. Tesis. Program Studi Magister Ilmu Ternak Program Pasca sarjana Fakultas Peternakan Universitas Diponegoro, Semarang.

Mahmilia, F., S.P. Ginting., A. Batubara., M. Doloksaribu dan A. Tarigan. 2004. Karakteristik Morfologi dan Performans Kambing Gembrong dan Kosta. Pros. Seminar Nasional Tekhnologi Peternakan dan Veteriner. Bogor, 4 - 5 Agustus 2004. Puslitbang Peternakan, Bogor. hlm. 375 380 .

Mitruka, B., et al., 2016. Study of Hospital Based Epidemiology and Clinical Types of Cases of Dermatophytosis Presenting in Outpatient Departement of Skin and Venereology. Scholars Journal of Applied Medical Science, 4 (5C) : 1603-1616.

Murray,Robert K, Graner, Daril K, Mayes Peter A, Rodwell Viktor W. 2003 Biokimia Harper ed. 25. Jakarta: EGC. P.236-239.

Nossafadli, M. R, Handarini dan E, Dihansih. 2014. Profil Darah Domba Ekor Tipis (Ovis aries) yang Diberi Ransum Fermentasi Isi Rumen Sapi. Jurnal Pertanian, 5 (2) : 95-103.

Rahayu, H., Rolizawaty., Amiruddin., Zuhrawaty., T.F.Karmil. 2017. Jumlah Eritrosit Kadar Hemoglobin dan Nilai Hematokrit Kambing Kacang Betina Di Kecamatan Koto XI Tarusan Kabupaten Pesisir Selatan.JIMVET, 1(2) : 101-108.

Rosadi F. 2013. Profil darah kambing peranakanetawah laktasi yang mendapat ransum denganberbagai level Indigofera sp. berbentuk pellet.Skripsi. Fakultas Peternakan, Institut Pertanian Bogor, Bogor.

Sarwono, B. 2008. Beternak Kambing Unggul. Penebar Swadaya, Jakarta.

Sumardianto, T. A. P., E. Purbowati, dan Masykuri. 2013. Karakteristik karkas kambing kcang, kambing peranakan ettawa, dan kambing kejobong jantan pada umur satu tahun. Animal Agriclulture, 2 (1) : 175-182. 
Suwandi. 2002. Manfaat Pemeriksaan Gambaran Darah Umum Pada Ternak Ruminansia.Temu Teknis Fungsional Non Peneliti. Balai Peneliti Bogor 133-139.

Steel, R. G. D. dan J. H. Torrie., 1993. Prinsip dan Prosedur Statistika (Pendekatan Biometrik) Penerjemah B. Sumantri. Gramedia Pustaka Utama, Jakarta.

Weiss, D.J and K.J. Wadrobe. 2010. Schlam's Veterinary Hematology. $6^{\text {th }}$ ed. Blackwell Publishing, USA.

Wahjuni, R.S., R. Bijanti dan R, Sidik. 2011. Profile Total Protein dan GlukosaDarah Domba yang Diberi Starter Bakteri Asam Laktat dan Yeast pada Rumput Gajah dan Jerami Padi. Jurnal Ilmu Kedokteran Hewan, Vol 4 No 1 : 65-70.

Wanapat, M., C. Promkot and S.Wanapat. 2006. Effect of Cassoyurea Pellet as a Protein Source in Concentrate on on Ruminal Fermentation and Digestibility in Cattle. Asian-Aust. Journal Animal Science 19 (7):1004 -1009 .

Widiyono, I., Sarmin, T. Susmiyati, B, dan Suwignyo. 2014. Studi nilai hematologik kambing kacang. ProsidingKIVNAS. Palembang. 